\title{
Konsep Etika dan Estetika Dalam Meningkatkan Service Quality Perbankan; Sebuah Kajian Literatur
}

\author{
Budi Satria ${ }^{1}$, Dhian Tyas Untari ${ }^{2, *}$ \\ ${ }_{1}^{1}$ Fakultas Bisnis dan IImu Sosial; Universitas Dian Nusantara; Jl. Tj. Duren Bar. 2 No.1, \\ RT.1/RW.5, Tj. Duren Utara, Kec. Grogol petamburan, Kota Jakarta Barat, Daerah Khusus \\ Ibukota Jakarta 11470; e-mail: budi.satria@undira.ac.id \\ 2 Fakultas Ekonomi dan Bisnis, Universitas Bhayangkara Jakarta Raya; Jl. Raya \\ Perjuangan, Marga Mulya, Bekasi Utara, Jawa Barat 17121. Telp: 021-88955882, 889955883; \\ e-mail: tyas_un@yahoo.co.id \\ * Korespondensi e-mail: tyas_un@yahoo.co,id
}

\begin{abstract}
Demand of bank services is increasingly day by day, and in outher way, competition of banking industry also rigorous. And it made banking industry more colerfull than before. Product feature and fast, easy also save services is a key of successful competition in baking industry. To invent product and excellence service quality is related to how we can improve our human resources. Every human resources must understand about professional ethic and aesthetics of behavior. That is very important for them because they alweys having interaction with bank customer. This is a conceptual paper that will discribe the relation between ethic, aesthetics and service quality in banking industry. And expected this paper will give a new discourse to develop banking industry in Indonesia by increasing competitiveness of humand resourses
\end{abstract}

Key words : Ethic, aesthetics, service quality

\begin{abstract}
Abstrak
Permintaan jasa bank semakin hari semakin hari, dan di luar itu persaingan industri perbankan juga semakin ketat. Dan itu membuat industri perbankan lebih penuh warna dari sebelumnya. Fitur produk dan layanan yang cepat, mudah juga menyimpan adalah kunci dari persaingan yang sukses di industri kue. Menemukan kualitas produk dan layanan yang prima berkaitan dengan bagaimana kita dapat meningkatkan sumber daya manusia kita. Setiap SDM harus memahami tentang etika profesi dan estetika perilaku. Itu sangat penting bagi mereka karena mereka selalu berinteraksi dengan nasabah bank. Ini adalah makalah konseptual yang akan menggambarkan hubungan antara etika, estetika dan kualitas layanan di industri perbankan. Dan diharapkan tulisan ini dapat memberikan wacana baru untuk mengembangkan industri perbankan di Indonesia dengan meningkatkan daya saing sumber daya manusia
\end{abstract}

Kata kunci: Etika, estetika, kualitas pelayanan

\section{Pendahuluan}

Secara umum perkembangan dunia bisnis saat ini mengalami pertumbuhan yang sangat pesat, baik bisnis yang bergerak di bidang manufaktur maupun jasa. Perkembangan perekonomian secara menyeluruh yang diiringi dengan perkembangan teknologi dan ilmu pengetahuan menciptakan sebuah persaingan yang semakin ketat dan tajam, baik di pasar domestik maupun di pasar internasional.Oleh karena itu dalam persaingan yang demikian, perusahaan dituntut untuk dapat memuaskan pelanggannya dengan menciptakan produkproduk berkualitas sesuai dengan keinginan konsumen

Kompleksitas persaingan perbankan di Indonesia relatif lebih tinggi juka dibanding dengan negara-negara di Asia Tenggara lainnya. Bahkan untuk masa yang akan datang persaingannya tidak hanya persaingan antarbank, tapi persaingan akan semakin berwarna 
dengan masuknya persaingan antar lembaga keuangan yang tentunya masih melibatkan perbankan.

Sebagai lembaga keuangan yang usaha utamanya memberikan jasa penyimpanan dan menyalurkannya kembali dalam berbagai alternatif pinjaman kepada masyarakat juga perlu memfokuskan pada kinerja pelayanan untuk memuaskan pelanggannya.

Pelayanan bagi dunia perbankan adalah kunci yang membedakan suatu bank dengan pesaingnya, sehinggga memegang peranan penting dalam pencapaian tujuan perusahaan.Industri jasa perbankan ini sangat terkait erat dengan kepercayaan, service (layanan), dan hubungan yang dekat berpadu interaksi terbaik kepada nasabah. Suatu paradigma yang selama ini menganggap service merupakan tanggungjawab penuh dari karyawan yang berada di front liners (garda depan) sudah seharusnya diubah. Sinergitas antar karyawan dengan multi posisi menjadi sangat penting untuk dapat menghasilkan sebuah layangan yang maksimal.

Dengan uraian tersebut penulis tertarik untuk mengkaitkan antara meningkatkan Service Quality perbankan dengan Etika dan Estetika yang menjadi dasar bagi pemberian pelayanan yang maksimal kepada nasabah perbankan. Tulisan ini diharapkan dapat menjadi sebuah wacana baru dalam menyususnan strategi pelayanan dalam perbankan dalam mengatasi persaingan yang semakin ketat dengan usahanya merebut dan memepertahankan nasabah.

\section{Kajian Literatur \\ 2.1 Peta Perbankan Di Indonesia}

Berdasarkan aset Peta perbankan di Indonesia digambarkan dengan empat kluster. Kluster pertama adalah bank-bank dengan aset di atas Rp 200 triliun. Kluster kedua, bank-bank dengan aset dari Rp 100 triliun sampai Rp 200 triliun. Kluster ketiga, bank-bank beraset Rp 50 triliun sampai Rp 100 triliun. Kluster keempat, bank-bank dengan aset di bawah Rp 50 triliun. Dimana masing-masing kluster memiliki tingkat kompleksitas persaingan yang berbeda. Sehingga masing-masing kluster memiliki dinamika pasar yang berbeda

Persaingan di kluster pertama akan diwarnai dengan persaingan merebut pangsa pasar yang mana pemimpin pasar akan berupaya kuat mempertahankan posisinya. Layanannya pun lebih luas, menjangkau sekuritas, reksa dana, maupun asuransi. Sementara, di kluster kedua, persaingannya lebih kompleks. Posisi tanggungnya membuat bank-bank di posisi ini bersaing dengan bank di kelasnya sekaligus dengan bank-bank di atasnya. Kunci sukses memenangkan persaingan kluster ini adalah transformasi layanan yang menjadikan layanannya bersifat menyeluruh. Kluster ketiga merupakan kluster menengah kecil yang mana pemainnya memiliki sumber daya yang lebih terbatas. Persaingannya akan lebih khusus dengan mengusung keunggulan kompetitifnya dan layanan lengkap bagi pelanggan di klusternya. Kunci sukses memenangi persaingan tak lain adalah strategi selektif memilih pasar yang dituju. Kluster keempat memiliki persaingan unik karena pasar yang tersedia lebih terbatas sehingga untuk bertahan, para pemain berupaya mengembangkan dan memperluas jaringan di sektor mikro. Biasanya, pemain di sektor ini akan mengalami kendala dalam investasi dan perluasan jaringan. Sindikasi bisa menjadi salah satu cara untuk sukses di sektor ini.

\subsection{Mutu Pelayanan}

Mutu adalah sebuah kata yang bagi penyedia jasa merupakan sesuatu yang harus dikerjakan dengan baik. Aplikasi mutu sebagai sifat dari penampilan produk atau kinerja merupakan bagian utama strategi perusahaan dalam rangka meraih keunggulan yang berkesinambungan, baik sebagai pemimpin pasar ataupun sebagai strategi untuk terus tumbuh (Kotler, 2000).

(Parasuraman et al., 1991) membentuk model mutu pelayanan yang menyoroti syarat syarat utama yang memberikan mutu pelayanan yang diharapakan.

Adapun model ini mengidentifikasikan lima kesenjangan yang mengakibatkan kegagalan penyampaian jasa, yaitu:

[1]. Kesenjangan antara harapan konsumen dan persepsi manajemen. Dalam hal ini manajeman tidak selalu memahami benar apa yang menjad keinginan pelanggan.

[2]. Kesenjangan antara persepsi manajemen dan spesifikasi mutu pelayanan. Dalam hal ini manajemen mungkin benar dalam memahami keinginan pelanggan, tetapi tidak menetapkan standar pelaksanaan yang spesifik. 
[3]. Kesenjangan antara spesifikasi mutu pelayanan dan penyampaian jasa. Dalam hal ini para personel mungkin tidak terlatih baik dan tidak mampu memenuhi standar.

[4]. Kesenjangan antara penyampaian jasa dan komunikasi eksternal. Dalam hal ini harapan konsumen dipengaruhi oleh pernyataan yang dibuat wakil - wakil dan iklan perusahaan.

[5]. Kesenjangan antara jasa yang dialami dan jasa yang diharapkan. Dalam hal ini terjadi bila konsumen mengukur kinerja perusahaan dengan cara yang berbeda dan memiliki persepsi yang keliru mengenai mutu pelayanan.

\subsection{Dimensi Kualitas Jasa}

Menurut (Parasuraman et al., 1991)vberdasarkan penelitianya untuk mengetahui konsep dari mutu pelayanan menyebutkan bahwa mutu pelayanan yang diterima dinyatakan dalam ukuran besarnya ketidaksesuaian antara harapan dan keinginan dengan tingkat persepsi mereka terhadap pelayanan yang akan diperoleh.

Persepsi dari kualitas pelayanan selanjutnya diinterpretasikan pada perbedaan antara persepsi mutu pelayanan dan harapan yang akan diterima oleh konsumen. Sehingga, mutu pelayanan dikemukakan memiliki 5 (lima) dimensi atau SERVQUAL, dimana instrument ini dapat digunakan secara umum oleh perusahaan - perusahaan jasa terdiri dari: 1.Tangible ( berwujud) seperti penampilan fasilitas fisik, peralatan, personel dan media komunikasi, 2. Reliability (keandalan) yaitukemampuan untuk melaksakan jasa yang dijanjikan dengan tepat dan terpercaya, 3. Responsiveness (daya tanggap) yaitu kemauan untuk membantu pelanggan dan memberikan jasa dengan cepat atau ketanggapan, 4.Assurance (keyakinan) yaitu pengetahuan dan kesopanan karyawan serta kemampuan mereka untuk menimbulkan kepercayaan dan keyakinan atau assurance, dan 5. Empathy (empati) yaitu syarat untuk peduli, memberi perhatian pribadi bagi pelanggan. Untuk perhitungan skor SERVQUAL, dapat menggunakan rumus perhitungan sebagai berikut (Zeithaml, 1990), Dengan membandingkan harapan dan persepsi pelanggan itu akan diketahui kepuasan mereka, baik untuk tiap atribut, dimensi, maupun secara keseluruhan. Tetapi dalam penggunaannya terdapat beberapa kelemahan yaitu :

[1]. SERVEQUAL hanya mengukur dua faktor yaitu : intrinsic service quality dan extrinsic service quality. Tidak mengukur construct in service quality (Christhoper, 2004)

[2]. Untuk menerapkan SERVEQUAL, dibutuhkan definisi spesifik yang secara operasional dapat diterapkan masing - masing industri jasa (Jafar, 2005).

Untuk menutupi kelemahan yang ada unsur Compliance pada dimensi mutu pelayanan yang diteliti sebelumnya oleh Parasuraman, yang bisa dikenal dengan Compliance with Islamic law (kepatuhan terhadap hukum Islam). Lima dimensi mutu pelayanan ditambah dengan dimensi compliance sebagai syarat produk atau jasa syariah, yang lebih dikenal dengan CARTER, yakni : Compliance, which means the ability to fulfill with Islamic law and operate under the principles of Islamic banking and economy. (Kepatuhan, yang berarti kemampuan untuk memenuhi dengan hukum Islam dan beroperasi di bawah prinsip - prinsip perbankan Islam dan ekonomi).

\subsection{Kepuasan Nasabah Perbankan}

Inti dari kegiatan oprasional bisnis adalah mengetahui keinginan nasabah serta berusaha memuaskan keinginan tersebut. Nasabah yang puas akan sebuah produk/ jasa mempunyai kecenderungan untuk mengkonsumsi produk/jasa tersebut berulang kali, hal itu akan menciptakan konsumen yang loyal/setia. Pada akhirnya konsumen yang loyal akan meningkatkan profit perusahaan.

Kepuasan nasabah perbakan dipengaruhi oleh dua faktor, yakni harapan nasabah akan kinerja sebuah produk/jasa, dan kenyataan yang mereka terima setelah mengkonsumsi produk/jasa tersebut. Nasabah akan merasa puas jika kinerja produk/jasa sama atau bahkan melebihi harapan semula. Sebaliknya, konsumen akan tidak puas jika kinerja produk/jasa tidak sesuai dengan harapannya.

Menurut (Kotler, 2000), (Sunarto, 2006), (Yazid, 2005) kepuasan adalah perasaan senang seseorang yang muncul setelah membandingkan kinerja (hasil) produk yang dipikirkan terhadap kinerja (atau hasil) yang diharapkan. Dan menurut (Untari, 2018) kepuasan pelanggan adalah respons berupa perasaan puas yang timbul karena pengalaman mengonsumsi suatu produk atau layanan, atau sebagian kecil dari pengalaman itu. Kepuasaan pelanggan hunt 
dalam (Untari, 2019) mengkelompokkan kepuasan dalam beberapa perspektif definisi yakni :1) Normatif deficit definition, 2) Equity defenition, 3) Normatif standar defenetion, 4) Prodecural fairnes definition dan 5) Attributional definition.

Kepuasan konsumen didefinisikan sebagai penilaian evaluasi pascapembelian dimana alternatif yang dipilih sekurang - kurangnya memberi hasil sama atau melampaui harapan konsumenseperti terlihat pada tabel berikut:

Tabel.2 Expectation, Performance and Satisfaction Kinerja aktual

\begin{tabular}{lll}
\hline $\begin{array}{l}\text { Kinerja aktual } \\
\text { dibandingkan harapan }\end{array}$ & $\begin{array}{l}\text { Di bawah minimum } \\
\text { desire performance }\end{array}$ & $\begin{array}{l}\text { Di atas minimum } \\
\text { desire performance }\end{array}$ \\
\hline Lebih baik & Kepuasan & Kepuasan/komitmen \\
\hline Sama & Non-satisfaction & Kepuasan \\
\hline Lebih buruk & Ketidakpuasan & Ketidakpuasan \\
\hline Sumber: Hawkins, Mothersbaugh \& Best (2007) &
\end{tabular}

\subsection{Tipe- Tipe Kepuasan Nasabah Perbankan}

Stauss \& Neuhaus (Untari \& Satria, 2014) membedakan tiga - tipe kepuasan dan dua tipe ketidakpuasan, yakni :

[1]. Demanding customer satisfaction. Tipe ini merupakan tipe kepuasan yang aktif. Adanya emosi positif dari nasabah, yakni optimisme dan kepercayaan.

[2]. Stable customer satisfaction. Nasabah dengan tipe ini memiliki tingkat aspirasi pasif dan perilaku yang menuntut emosi positifnya terhadap penyedia jasa bercirikan steadiness dan trust dalam relasi yang terbina saat ini. Nasabah menginginkan segala sesuatunya tetap sama.

[3]. Resigned customer satisfaction. Nasabah dalam tipe ini juga merasa puas. Namun, kepuasannya bukan disebabkan oleh pemenuhan harapan, namun lebih didasarkan pada kesan bahwa tidak realistis untuk berharap lebih.

[4]. Stable customer dissatisfactio. Nasabah dalam tipe ini tidak puas terhadap kinerjanya, namun mereka cenderung tidak melakukan apa-apa.

[5]. Demanding dissatisfaction. Tipe ini bercirikan tingkat aspirasi aktif dan perilaku menuntut. Pada tingkat emosi, ketidakpuasannya menimbulkan protes dan oposisi.

\subsection{Konsep Etika dan Estetika di Dunia Perbankan}

Istilah Etika berasal dari bahasa Yunani kuno. Bentuk tunggal kata 'etika' yaitu ethos sedangkan bentuk jamaknya yaitu ta etha. Ethos mempunyai banyak arti yaitu : tempat tinggal yang biasa, padang rumput, kandang, kebiasaan/adat, akhlak,watak, perasaan, sikap, cara berpikir. Sedangkan arti ta etha yaitu adat kebiasaan. Arti dari bentuk jamak inilah yang melatar-belakangi terbentuknya istilah Etika yang oleh Aristoteles dipakai untuk menunjukkan filsafat moral. Jadi, secara etimologis (asal usul kata), etika mempunyai arti yaitu ilmu tentang apa yang biasa dilakukan atau ilmu tentang adat kebiasaan (Bertens, 2000).

Sedangkan estetika berasal dari kata Yunani aesthesis yang berarti perasaan, selera perasaan atau taste. Dalam prosesnyan Munro mengatakan bahwa estetika adalah cara merespon terhadap stimuli, terutama lewat persepsi indera, tetapi juga dikaitkan dengan proses kejiwaan, seperti asosiasi, pemahaman, imajinasi, dan emosi. Ilmu estetika adalah suatu ilmu yang mempelajari segala sesuatu yang berkaitan dengan keindahan, mempelajari semua aspek dari apa yang kita sebut keindahan.

Estetika adalah hal yang mempelajari kualitas keindahan dari obyek, maupun daya impuls dan pengalaman estetik pencipta dan pengamatannya. Estetika dalam kontek penciptaan menurut John Hosper merupakan bagian dari filsafat yang berkaitan dengan proses penciptaan karya yang indah. Terkait dengan dipermasalahan di dunia perbankan dimana layanan menjadi kunci dalam pelaksanaan oprasionalnya, dan sumber daya manusia merupakan aset utama dimana manusialah yang menjadi mind factor pelaksanaan layanan, maka etika dan estetika sangat erat dalam peningkatan kualitas layanan di dunia perbankan. Pemberikan pelayanan dengan baik yang menjadi sebuah budaya dalam pelaksanaan bisnis perbankan serta keindahan dalam penyampaian layanan baik menyangkut intangiable dan tangiable menjadi tantangan tersendiri dalam pelaksanaan layanan di dunia perbankan. 


\subsection{Empirisme Etika Dan Estetika Perbankan di Indonesia}

Bisnis perbankan merupakan suatu aktivitas yang sarat dengan liku-liku hidup subyek pelaku bisnis yang terkait dalam dunia perbankan. Seperti halnya liku-liku hidup yang menggiring manusia sebagai sumber daya pengelolaan dan pengendali, namun pada saat-saat menghadapi bisnis yang semakin melanda secara global muncul perilaku-perilaku manusia dalam hal ini sebagai sumber daya yang diharapkan untuk menumbuh kembangkan dunia perbankan namun semakin cenderung ada peningkatan untuk tidak mempertahankan norma sehingga etika dan estetika bisnispun luntur sehingga kebobolan bank sudah menjadi biasa. Akibatnya masyarakat luas semakin menipisnya kepercayaan terhadap dunia perbankan yang sebenarnya merupakan pusat dinamika denyut jantung roda perekonomian.

Bank sering disebut lembaga kepercayaan, terutama masyarakat yang mempercayai bank untuk menghimpun dana mereka dan selanjutnya disalurkan kembali ke dalam berbagai alternatif investasi. Berbeda dengan perusahaan lain, transaksi usaha bank senantiasa berkaitan dengan uang, karena memang komoditi usaha adalah uang.

Perlu diketahui bahwa proses pemberian rating (peringkat) dari suatu pemeringkat, contohnya Standard and Pore's Rating Agency (S\&P) di Australia, Moodys Investor Service Ltd. (AS) Capital Intelligence (Cyprus) dan dari dalam negeri PT. REFINDO (Pemeringkat Efek Indonesia). Mereka melakukan evaluasi untuk mengetahui credit worthiness atau kredibilitas surat-surat berharga yang diterbitkan oleh perusahaan. Yang menjadi salah satu indikator evaluasi itu tidak hanya melihat bidang organisasi, manajemen, berdaya kerja, tapi yang sangat menentukan dan tidak kalah penting adalah etika dan estetika bisnis yang dijalankannya.

Dalam rangka mengantisipasi globalisasi di bidang perdagangan dan industri, khususnya sektor perbankan, maka sudah jelas bahwa tidak hanya segi strategi kompetisi, organisasi, teknologi, namun yang menyangkut sumber daya manusia termasuk didalamnya adalah etika dan esteika bisnis dalam pelasanaan layanan perbankan. Etika dan estetika bisnis cukup memadai setiap dunia usaha termasuk etika dan estetika bisnis perbankan. Hanya saja dalam realitas kongkrit operasional masih sering diketemukan bahwa prinsip-prinsip etika dan estetika bisnis sering tidak berjalan sebagaimana mestinya. Timbul pertanyaan apa yang menyebabkan praktek bisnis tidak berjalan sesuai dengan apa yang digariskan dalam prinsipprinsip etika dan estetika bisnis diatas.

\section{Kesimpulan}

Persaingan bisnis pada dunia perbangkan kian ketat, sehingga menjadi hal yang cukup logik bagi pengelola bisnis perbankkan untuk meningkatakan kualitas produk perbankan yang dimilikinya. Perbankan merupakan sebuah perusahaan dengan service atau layanan sebagai mind core product-nya. Dan dengan demikain manusia menjadi aset utama bagi perbankan untuk dapat meningkatkan layanan. Sehingga peningkatan kualitas sumber daya manusia dalam pelaksanaan layanan menjadi sebuah kewajiban dalam pengembangan bisnis perbankan. Etika dan estetika merupakan sebuah pengembangan budaya kerja yang bebasis pada moralitas dan etika dalam pelaksanaan layanan perbankan, selain itu hal yang terkait dengan keindahan baik secara intangiable maupun tangiable juga menjadi hal yang dapat dapat mendukung kualitas layanan dalam bisnis perbankan. Sehingga dengan demikian, konsep etika dan estetika dalam meningkatkan kualitas layanan sebuah bisnis perbankan adalah sesuatu yang mutlak diperhatikan dalam mengembangkan bisnis perbankan dan memenangkan persaingan.

\section{Daftar Pustaka}

Bertens, K. (2000). Pengantar Etika Bisnis. Alpha.

Christhoper, L. (2004). Service Marketing, Fifth Edition. Prentice Hall.

Jafar, F. (2005). Manajemen Jasa Pendekatan Terpadu, Cetakan Pertama. Ghalia. 
Submitted: 4 Agustus 2020; Revised: 19 Agustus 2020; Accepted: 15 September 2020; Published: 30 September 2020

Kotler, P. (2000). Marketing Management Millenium Edition.Pdf. Https://Www.Perspectiva.Md/Ro/Files/Biblioteca/Kotler-

Marketing\%20management\%20millenium\%20edition.Pdf

Parasuraman, Berry, \& Zeithaml,. (1991). Refinement And Reassessment Of The Servqual Scale. Journal Of Retailing, 67((4) Winter.), 420-450.

Sunarto. (2006). Riset Pemasaran. Singapure Marshal.

Untari, D. T. (2018). Metodologi Penelitian: Penelitian Kontemporer Bidang Ekonomi Dan Bisnis. In Metodologi Penelitian: Penelitian Kontemporer Bidang Ekonomi Dan Bisnis (Vol. 1, Pp. 1-192). Pena Persada. Https://Books.Google.Co.Id/Books?ld=R7gdwaaqbaj\&Pg=Pa183\&Dq=Dhian+Tyas+Untari\&HI=Id\&Sa=X\&Ved=0ahukewiowz7szz _Pahxs6nmbhbpmbraq6aeikdaa\#V=Onepage \&Q=Dhian\%20tyas\%20untari\&F=False

Untari, D. T. (2019). The Development Strategy Of Betawi Eco-Culinary Tourism As A Potential Business In Dki Jakarta, Indonesia. African Journal Of Hospitality, Tourism And Leisure, 8(Special Edition Cut), 1-8.

Untari, D. T., \& Satria, B. (2014). Strategi Pengembangan Pemasaran Laksa Tangerang Sebagai Salah Satu Produk Wisata Kuliner Di Tangerang. Jurnal Manajemen, 10(2), 4964.

Yazid. (2005). Pemasaran Jasa. Ekonisia.

Zeithaml. (1990). Zeithaml, V, Et Al, 1990, Delivering Quality, 5th Edition,. Macmillan Inc. 